\title{
THE SONG OF THE SQUIRT
}

by

\section{SIR ERNEST FINGH}

ThIS miscellany was written seventy years ago by Dr. James Hurd Keeling (1831-1909) M.D. (Edin.), M.R.C.S., L.S.A., F.R.C.S. (Eng.). It was never published but was circulated to a few friends. Copies are very scarce and it seems proper that it should be published as it throws a sidelight on the effect of the discovery of the tubercle bacillus and tuberculin both on the medical and bacterial world.

James Keeling was born in Malta, the son of a Wesleyan minister. He was educated at a Wesleyan school in Leeds, the University of Edinburgh, and subsequently in London, Paris and Vienna. In 1853 he was an assistant in a practice at Staveley in Derbyshire but in 1854, on the outbreak of the Crimean War, he volunteered for service with the Turkish Army and served with the 'second Turkish contingent'. He was awarded the decoration of the Order of Medjidie. In 1858 he settled in practice in Sheffield and in 1860 was appointed Lecturer in Medical Jurisprudence in the Medical School. The affairs of the school were then in an unsatisfactory condition and an attempt was made to close it; this was prevented by James Keeling who played an important part in its re-organization. In 1862 he was appointed an honorary surgeon to the Public Hospital and Dispensary, now the Royal Hospital. He resigned this appointment in 1887 in order to devote himself entirely to obstetrics and gynaecology at the Jessop Hospital for women which had been founded by the generosity of Mr. Thomas Jessop in 1864. In 1865 three honorary surgeons were appointed, of whom Dr. James Keeling was the senior. The Jessop Hospital was enlarged in 1902 and he not only himself gave financial help but also was instrumental in obtaining it from others. He retired from the staff of this hospital in 1906 and died on 15 March 1909 . He was one of the two local secretaries when the British Medical Association visited Sheffield in 1876. The writer of the obituary notice (Brit. med. F., I909, 1, 76r), stated:

He contributed many papers to the Medical Chirurgical Society of Sheffield but published nothing. He was a man of marked ability, well versed in medical literature and possessed a ripe and varied experience. He was very reserved, delighting in secret kindness and selfsacrificing labour, but received any acknowledgement of his good deeds with characteristic brusqueness.

It would be well to say something of the background of the song. Robert Koch (1843-1910) discovered the tubercle bacillus in 1882 . In 1890 he described the preparation and properties of tuberculin and claimed that, when properly used, it was a specific for the cure of tuberculosis in the human being. 'This statement created the greatest excitement throughout the medical world', and amongst other places in Sheffield. Tuberculin failed as a specific, but later it 


\section{Sir Ernest Finch}

was found to be of the greatest service in the recognition of tuberculosis in man and animals; its discovery was undoubtedly a great contribution to the progress of diagnostic medicine. The opinion as to the specificity of tuberculin differed to such an extent in various medical centres and were so contradictory and confusing that the Medico-Chirurgical Society of Sheffield in 1890 decided to send two of its senior members as a deputation to Koch's clinic in Berlin to make their own investigations on behalf of the society. When they returned they made a full report to the society stating what they had seen, the details of the preparation and treatment by tuberculin, the cost and the results in the cases which they had examined; they were not impressed with the latter. The tuberculin had to be given therapeutically by hypodermic injection. There is controversy as to who introduced the hypodermic syringe; in the song it is stigmatized as a squirt.

The most convincing claim is that of the Edinburgh School that Alexander Wood secundus (1817-84) introduced it into Great Britain in 1853 . The Dublin School claim that it was introduced into Europe by Francis Rynd (180I-6I) in 1845 when he was a surgeon on the staff of the Meath Hospital in Dublin; whereas the French claim that Charles Gabriel Pravaz of the Veterinary College in Lyons was responsible for its general use. It was not used in America till 1856 at the earliest. The evidence in support of these various claimants was carefully recorded by Dr. G. A. Mogey of the Department of Pharmacology, University of Leeds in 1953 (Brit. med. F. 1953, II, 1180 ).

The museum at Trinity College, Dublin contains the original syringe used by Rynd, and the museum at the Royal College of Surgeons of Edinburgh that of Alexander Wood. They differ in structure but not in function.

The following is an abstract from the prologue to the song:

On 16 December 1890 a special meeting of the Committee of the Sheffield Medico-Chirurgical Society was held at the house of the President, to partake of an oyster supper.

Soon after the meeting had commenced the proceedings were interrupted by an attendant who gave the President a visiting card bearing the name of 'Mr. Jejeunum Bacillus' and also a letter marked 'urgent'. None of the company would admit any personal acquaintance with Mr. Bacillus as his reputation at that time was particularly evil. The President put it to the meeting whether the letter should be read. After some discussion it was decided that the President should read the letter to the assembled company. It was written from the address Glossop Road Flags, Sheffield, I6 December 189o. It contained lurid details of how Mr. Bacillus a few nights previously had been thrown out of a hospital in Berlin on to the pavement of the street. He had previously been living in the hospital for a long time and so far as he knew he had been at peace with all men. After a momentary concussion, due to his impact with the pavement, he was roused by hearing English spoken with a Scot's accent by a big burly man talking to his companion, obviously an Englishman. They had dined well and were deciding to return to England the next day. Mr. Baccillus decided to accompany them. It continued: 


\section{The Song of the Squirt}

so I climbed up the clothes of the man nearer to me and I crept under his coat collar. For the next three days I managed to nourish myself on some fluff beneath the coat collar and reached London; later in the day I arrived in Sheffield with my companions. I was proposing to stay with them when to my horror my host took from his pocket one of those villainous Koch squirts which had caused me and my comrades so much suffering in Berlin. By chance I found an invitation to supper from you Mr. President; true it was not intended for me, but I have come. There is an old saying Mr. President, 'no song no supper'; if the converse is true I am prepared to produce the words of the song. It is called 'The Song of the Squirt' and relates some of my recent thoughts resulting from a squirt.

The letter was signed 'Jejeunum Bacillus'. The company voted to hear the words of the song. Mr. Jejeunum Bacillus was then invited to come in and he read the words of the song which are as follows:

I'm a small and frail Bacillus

But I hail from a mighty host

A few years ago not a soul did know

From whence we came, nor whither we go,

Nor how we are born, nor how we grow

Indeed there was very little to show

whether we even existed.

But now the whole world with our prowess is ringing,

And Koch, in his pride, a defiance is flinging,

With poisonous brew he dares to pursue us,

With a sharp little squirt he swears to undo us,

For him and his crew, for me and my peers,

With a boundless faith and very long ears,

Or in cautious suspense, or with low muttered jeers

Of doctors and patients; with the smiles and the tears

Of the learned and simple, the hopes and the fears

Of the whole world are enlisted.

I'm a hoary old Bacillus

And come of an ancient race.

Long before Adam I roamed the earth,

I was in at the death, and I watched the birth

Of all that creeps, or swims, or flies,

No matter their shape, no matter their size.

Would you know my business? That's easy to say

There was always some rubbish to clear away,

So I came to cleanse, to save, to slay,

As the case might be, but mark, I pray

My chief intention, as I'm a sinner

Was simply to obtain my dinner.

So when there was plenty of food about, And nobody there to turn us out, We stayed, and soon invited our chums, And then we made merry and filled our 'tums' And brought up our babies, and packed the place

For our progeny grows at a fearful pace. 


\section{Sir Ernest Finch}

Sometimes our landlord would growl and groan Cough some of us out, and then with a moan Swear all was in vain, meanwhile he grew thin, For each one he spat out, a thousand stayed in. The silly old muff! why didn't he try

To starve us all out and stop the supply

Of the rotten old tissues which we lived by.

When all was eaten but shells and bones, We buried him deep midst the ancient stones, Or we sank him down in the marshy loch In those jolly old days when there was no Koch.

We were just a bit scared when Adam came, But we soon found out he tasted the same, Or worse-that is better-from our point of view For he and his children did all they know To ruin their bones, joints, glands and skins, Also their lungs by innumerable sins.

They fought and they feasted, got drunk and went whoring, And cursed as the fire and brimstone came pouring To burn up their bodies, now corrupted and rotten, Crammed full of disease, by their vices begotten, Since then the history is much the same Many Adamites follow the old bad game, So syphillis, tubercle, cancer, and gout Very quickly hunted the rascals out, Ruined their body, and stained their soul Until it was rare to find one whole.

All this gives joy to a meek Bacillus For their moribund cells each day do fill us.

We'd grown rather tired of guinea-pig diet Or rabbit, or rat, so one day on the quiet We ventured our luck on the lord of creation, And found we could feed on the whole of a nation. We invaded skin, lung, joint and gland, And more cosy nooks which came to hand, And there we revelled, a real merry band, On tissues and juice and the fat of the land. We are so tiny, so cunning and thin, There was hardly a place we couldn't get it.

Nobody saw us, no one detected us,

Years passed by the thousands before they suspected us.

I've dined on the monarch, and lunched on the slave, I've dined on the merry, and supped on the grave, On Roman and Greek, on Gentile and Jew, On Mandarin yellow and humble Hindoo, On red men and white, on tawny and black, I've eaten them all; the whole blessed pack. 


\section{The Song of the Squirt}

I'm fond of the young, the poor and the prude And were it not for the scarceness of food For our numberless hosts, I'd limit our dinners

To the useless old tissues of hardened old sinners.

I'm a bold and crafty Bacillus

And I've lived through the earth's evolution

Yet this upstart named Koch thinks he's able to kill us With his squirt, by injecting a horrid solution.

You've heard no doubt of this insolent man, How he wickedly hatched a murderous plan To follow us into our haunts and our dens Being armed with an oil immersion lens To watch us when eating, sleeping and waking;

Taking such liberties, with us his betters. If you doubt what I say, if your head you are shaking Then just read the journals, especially the letters.

He caught a few of our sillier lads, And addled their pates with his whimsical fads, He combed 'em, curled 'em, fed 'em and drilled 'em, He wormed out their secrets, then poisoned and killed 'em; And when they'd become like clay in his hands He lighted his fires and boiled 'em in pans.

I'm really a jolly Bacillus and love medicals dearly We're both of one trade, if you would only see it, We love a sick body, and both try to free it From the rubbish which clogs up each tissue and cell, And we're both very glad when the patient gets well As we enjoy the same trade, let's be honest and true I'm seeking my dinner and faith! so are you!

Cleanse the slums, limit the pubs, stop the smoke, clear the air, And the water, of all the foul things that they bear;

Give food to the needy and good clothing to wear,

Shut up the wild lads who turn night into day, And succour the women who lead them astray, When your race is again strong, healthy and fair, Rely on my word, you'll not find us there, When struma, syphilis, cancer and gout By cleanlier living have been driven out, When lechery's over, carousing and riot, We'll gladly return to our guinea-pig diet.

There are lots of good things besides man on the earth, With fish, flesh and fowl, there's no danger of dearth, And think of those oysters, an excellent dish, They look like a cross 'twixt a snail and a fish.

Koch says when we're gone, he'll clean up the place He'll patch up cracked walls, and paint up their face, But if you attempt to hurry us out With that villainous stuff they're hawking about; 


\section{Sir Ernest Finch}

If you tickle our tails with that damnable squirt There's someone, not us, who's sure to be hurt, If you poison our food, then of course we must go Somewhat shaken but still feeling fairly so-so.

As far as is known, it may very well be That we'll soon re-appear, quite frankly and free, So tell Pasteur and Koch or whoever they be That they've not seen the last of my comrades and me.

The company were of the opinion that the words of the song were sufficiently topical to justify an invitation to Jejeunum Bacillus, Esq. to join them at supper and so renew his acquaintance or even friendship with oysters.

So far as can be ascertained the words of the song were never set to music. 